\title{
Watchdogs in Our Midst: How Presidents Monitor Coalitions in Brazil's Multiparty Presidential Regime
}

\author{
Carlos Pereira \\ Mariana Batista \\ Sérgio Praça \\ Felix Lopez
}

\begin{abstract}
When delegating governing tasks to a coalition partner, the president would like to give a minister ample administrative powers to be able to effectively accomplish the political mission. Due to information asymmetries, the president runs the risk that this discretion might be used to pursue policy outcomes that may harm the president's preferences. This trade-off between delegation and control is key to understanding governance strategies the president chooses to minimize agency risks and coordinate public policies. With Brazil as a case study, this article demonstrates that presidents have strategically made frequent use of junior ministers as watchdogs of coalition partners, especially when coalition allies are ideologically distant from the president's preferences. Yet neither the portfolio salience nor the president's decision to share powers with coalition partners proportionally seems to interfere in such strategic decisions.
\end{abstract}

$\mathrm{P}$ residents in multiparty presidential regimes face a constant political dilemma: in order to govern and to sustain majority coalitions over time, presidents must allocate cabinet positions to coalition partners, granting them access to the policy and budgetary resources of the executive. At the same time, by delegating such political authority to parties in coalitions, presidents run the risk of being expropriated by appointed cabinet ministers who may not fully share the president's preferences. This is a typical agency problem. Delegating cabinet positions to coalition partners, the president gains legislative support to maintain a successful legislative agenda. However, once in control of a portfolio, the minister may pursue an agenda other than the president's.

Carlos Pereira is a professor in the Brazilian School of Administration (EBAPE) at the Getúlio Vargas Foundation. carlos.pereira@fgv.br. Mariana Batista is an assistant professor of political science in the Federal University of Pernambuco. mariana.bsilva@gmail.com. Sérgio Praça is an assistant professor in the School of Social Sciences (CPDOC) at the Getúlio Vargas Foundation. sergio.praca@fgv.br. Felix Lopez is a researcher in the Institute of Applied Economic Research (IPEA). felixglopez@gmail.com 
A lot has already been written about the stability of coalitions in presidential systems, the president's legislative strategies in deciding the partisan composition of the government, and the allocation of portfolios among coalition partners. The main issues in this literature are related to which parties will join the government, who gets what in portfolio allocation and other resources, how long the coalition (and specific ministers) will last, and the cost of coalition management. However, despite this growing literature, a relevant issue remains underexplored: coalition governance; that is, how presidents oversee coalition allies that are not necessarily completely aligned with presidents' policy platforms. This happens because partisan ministers represent political parties and constituencies of their own. Considering the information asymmetry between president and ministers, the risk of agency loss and policy drift in such a situation is imminent (Martínez-Gallardo and Schleiter 2015).

Agency risks are fundamental to the literature on coalition governance in parliamentary systems. The main argument is that ministerial government, the situation where cabinet ministers have total autonomy and individually dominate decisionmaking (Laver and Shepsle 1990, 1994), is suboptimal, and mechanisms of mutual control, such as coalition agreements, junior ministers, or legislative institutions, can achieve Pareto superior solutions (Müller et al. 2010; Thies 2001; Martin and Vanberg 2011; Carroll and Cox 2012).

The main goal of this article is to analyze coalition monitoring in the context of a presidential system, identifying when and how presidents decide to monitor coalition partners to minimize policy drift. This is important because, contrary to parliamentary systems, in which this process is more decentralized as a mutual control strategy, in presidential systems the president concentrates the decision of "whom to trust" (Martínez-Gallardo and Schleiter 2015).

By delegating powers of policy formulation and implementation to a minister, the president has two options: to accept the decisions and information provided by the minister or to attempt to minimize informational asymmetry and policy drift by monitoring the agent. One of the most important control mechanisms available to principals in multiparty coalitions is the appointment of junior ministers as "watchdogs" representing the president's preferences within cabinet positions. The junior minister is the second-in-command, and for this reason can monitor the minister's decisions, keeping them closer to the president's policy preferences. However, the presidential prerogative of appointing junior ministers is not unconstrained or cost-free.

If, on the one hand, the president decides to control a ministry by appointing a junior minister whom the president fully trusts, a close party mate or a career bureaucrat without a partisan affiliation, the president may reduce the chief minister's power and thus upset a coalition partner that supposedly was in charge of that particular ministry in the first place. The minister would have less room to impose the preferences of the coalition partner in the ministries' decisions, due to the ostensive monitoring of an "agent of the president," directly observing the decisionmaking. If, on the other hand, the president decides to delegate very broad authority and consequently to exercise loose control of the ministry's activities, the president may be surprised by the degree of policy drift by that particular subordinate. In case the 
president finds out that something is going wrong or in a different policy direction, it might be too late or too costly to undo the error. These governance dilemmas are at the forefront of the current debate over successful ways to manage coalition partners in multiparty settings.

Taking the Brazilian multiparty presidential regime as its case study, this article explores the political conditions under which the president chooses to monitor coalition partners by appointing a watchdog junior minister. The argument is that the greater the risk of policy drift, the greater the incentives for the president to monitor that particular minister by appointing a loyal junior minister. We argue that preference distance, portfolio salience, and the interaction of these two factors increase the incentives for monitoring due to risks of policy drift. We expect that the president will be more inclined to monitor coalition partners with watchdogs when those partners do not share policy preferences. The greater the portfolio salience, the higher the president's motivation to control ministers through watchdogs. Also, the effect of preference distance should be greater when the portfolio is salient.

In addition to that argument, we expect the degree of coalescence in the coalition (the proportionality between the number of cabinet positions and the number of seats held by a coalition party in the lower chamber) to affect the probability of monitoring individual ministers. This happens because in presidential systems, Gamson's Law of Proportionality (Gamson 1961) does not always hold, so we expect coalescence to act as a measure of coalition agreement among partners, such that the greater the coalition agreement, the smaller the incentives for monitoring.

Although we specifically investigate the political dilemma that Brazilian presidents have faced in deciding how to coordinate and monitor coalition partners, we hope that the particular theoretical and analytical exercises we propose here could travel well and extend to multiparty presidential regimes elsewhere. This article makes two relevant contributions to the literature. First, it provides the first analytical approach to coalition management that goes beyond anecdotal evidence of the use of junior ministers as overseers in presidential systems (Araya 2012). Second, it empirically analyzes the effect of three conditions under which the president would monitor a coalition partner (preference distance, portfolio salience, and coalescence). Other studies that investigate junior ministers as presidential watchdogs to control coalition allies have done so in an unsystematic manner (Rehren 1992, 71; Ferraro 2008, 118-19 for Chile; Martínez-Gallardo 2010, 128 for Argentina; and Loureiro et al. 2010, 106-7 for Brazil). This study is based on an original dataset comprising 178 pairings of ministers and junior ministers through four different Brazilian administrations from 1995 to 2010.

This article proceeds as follows. The next section reviews the relevant literature about delegation and monitoring of coalition partners in multiparty parliamentary and presidential regimes. The following section discusses case selection, data, and methods, and presents the descriptive assessment of the different types of junior ministers, the descriptive statistics, and the econometric exercises. The concluding section considers the implications of the main findings. 


\section{AgenCY Risks In MUlTiPARTY GOVERNMENTS}

In modern democracies, governing means delegation of powers. While delegation can be beneficial for political actors, since they can benefit from the agent's expertise and specialization, delegation also implies risks that an agent may use the power transferred by the principal against the principal's interests.

This happens because although coalition partners govern together, they are elected separately, and therefore have different constituencies, electoral strategies, and policy agendas (Martin and Vanberg 2011). What are the risks involved in governing together? How do coalition partners manage delegation to achieve the best outcomes?

The life cycle of coalition governments in parliamentary systems can be described in four basic stages: selecting a formateur, portfolio allocation, coalition governance, and termination. Initially, the literature focused on coalition formation and termination (stages 1, 2, and 4) and left coalition governance (stage 3), where delegation problems are managed, to be explored more recently.

The coalition formation game begins with the selection of a formateur among the legislative parties to define who gets into government and what share of the prize each party will gain. In the second stage, coalition partners decide whether to accept the offer to control a share of portfolios, or not. Deciding not to accept implies that the party will wait for another round of the bargaining process, even becoming the formateur eventually, or will not join the government, becoming opposition. This second stage can be defined as the process of dividing a prize, and usually ends with a proportional allocation of portfolios to coalition partners. This proportionality between portfolio share and seat share has come to be known as Gamson's Law, and is currently one of the most consistent associations in political science (Laver 1998). In traditional theories of coalition formation, the next stage is simply coalition termination, or explaining why governments break up and new coalitions are enacted (Laver and Shesple 1996).

However, there is an important third stage that remained unexplored for quite some time: coalition governance, or how coalitions actually govern. This is the focus of our analysis. This step is marked by delegation problems, since different parties with different preferences are involved in the decisionmaking. The problem at hand is whose preferences the coalition governments will reflect. Will it be the preferences of the individual parties, each controlling the decisions of their ministries, or is there a way to achieve decisions that reflect the collective preference of the coalition?

The first option would be a ministerial government, in which parties decide in the policy areas they control, and would equate to abdication by coalition partners (Laver and Shepsle 1990, 1994). This option may be suboptimal, since delegation can work better if coalition partners are monitored in a way that decisions reflect the preferences of the coalition and not of the individual parties (Thies 2001). This is the stage where the risk of agency loss has to be dealt with, because once in the cabinet and with no external constraints, a coalition partner has no incentive to imple- 
ment policies other than its own ideal point, expropriating the rest of the coalition (Laver and Shepsle 1990).

Considering this "delegation dilemma" (Martin and Vanberg 2011), there are several studies that identify potential monitoring mechanisms to "keep tabs on coalition partners" (Thies 2001). The main mechanisms are junior minister, coalition agreements, and parliamentary committees. The first two relate to intracoalition monitoring and the last to external oversight.

The first mechanism focuses on the idea that intracoalition monitoring is done mainly within the executive branch, through the use of watchdog junior ministers (Thies 2001; Verzichelli 2008; Lipsmeyer and Pierce 2011). Political parties with different ideologies and policy programs control each other through the appointment of partisan junior ministers. Party A appoints a junior minister to watch over the acts of the minister from party $\mathrm{B}$, and vice versa. The watchdog junior minister would function mainly as a whistleblower who informs the party (and thus the rest of the coalition) if the minister is deviating from the coalition's informal policy package (Martin and Vanberg 2011) or formal coalition agreement (Indridason and Kristinsson 2013). The main condition for the appointment of a watchdog junior minister is the preference divergence between coalition partners.

Building on Thies 2001, Lipsmeyer and Pierce (2011) argue that both coalition characteristics and institutional arrangements should affect how and when junior ministers are used for oversight purposes in parliamentary regimes. They find that coalition partners use junior ministers as watchdogs when the stakes are high, the differences between the parties are substantial, and they lack other means of overseeing their partners. This translates into oversight by junior ministers being more likely in ministries that implement policies of high salience, when the minister is from a smaller coalition party, and when committee systems are weak.

From an intracoalition and within-the-executive perspective, by contrast, Müller and Strøm (2000) consider coalition agreements as a mutual control mechanism. These agreements, usually made by coalition partners at the government's formation as one of the bargaining elements, specify policies to be enacted and decisions to be made and implemented by the cabinet, restricting ministerial autonomy. These agreements, which in most parliamentary democracies are formal, can specify a large number of situations, crystallizing a set of decisions against the autonomy of the agents responsible for the portfolio. Analysis of the agreements shows that specific policies and rules of conflict resolution, such as inner cabinets, are the main topics, indicating the actors' concern with ministers' control in the decisionmaking process (Müller and Strøm 2000). The main variable explaining monitoring through coalition agreements, according to these authors, is the ideological distance between coalition partners.

The third most explored monitoring mechanism is the role of the legislature. Legislative committees work as oversight mechanisms through which party X, which heads, say, the Committee on Foreign Affairs, checks the acts of the minister of foreign affairs, who belongs to party Y. Committee chairs can function as "bill delayers" through the strategic appointment of rapporteurs (as well as through the use of "minor" institutional arrangements allowed by the parliament's standing orders) or 
as whistleblowers who communicate to the coalition what a minister from a rival party is up to, thus minimizing informational asymmetry between the executive and the legislature. This argument has been systematically put forth by a number of influential scholars (Muller et al. 2010; Martin and Vanberg 2011; Carroll and Cox 2012), as well as a host of case studies (Kim and Loewenberg 2005; Giannetti and Laver 2005). The most relevant conditions for the use of committees as a mutual control mechanism are the institutional strength of the legislature and the committee system, the ideological distance between coalition partners, and issue salience.

The study of coalition governments in presidential systems can directly benefit from this knowledge of how coalitions work in parliamentary systems. However, institutions matter, and certain rules differentiate presidential and parliamentary systems. For instance, the stages of the coalition life cycle in presidential systems are very different from those in parliamentary systems. No formateur is selected; in a presidential system, the head of the government is directly elected, and therefore the formateur is exogenously defined. That said, the second stage also works very differently, since the president is always in the coalition, no matter the seat share that the president's party holds in the legislature. Also, this implies that Gamson's Law will not work the same way in presidential systems because the president's party may claim a disproportionate share of the cabinet portfolios. Furthermore, we can only speak of "coalition termination" in a less formal way, since there are no requirements to form a new government when the partisan composition of the governing coalition changes. More important, changes in the coalition do not imply the possibility of an election, since a government's duration is also exogenously defined by the fixed term of the president.

These differences between presidential and parliamentary systems have contributed to a fast-growing literature specializing in coalition formation (Alemán and Tsebelis 2011; Amorim Neto 2006; Martínez-Gallardo and Schleiter 2015), governance (Inácio and Llanos 2016; Batista 2013; Siavelis 2016; Inácio and Rezende 2015), management (Raile et al. 2011), cost (Pereira et al. 2016), and termination (Martínez-Gallardo 2012) in presidentialism. Alemán and Tsebelis (2011) argue that presidents have greater incentives to form multiparty coalitions when the balance of power leans toward the legislature and will include parties ideologically aligned in a way to reduce governing costs and possible policy drift. Portfolio allocation, the degree of partisanship, the coalescence rate, and the majority status will depend on the president's decision to govern through the legislature or unilaterally. The coalescence rate varies a lot between governments and is generally far from the proportionality rule observed in parliamentary regimes (Amorim Neto 2006).

Portfolio allocation may also be considered from the perspective of the risk of policy drift in multiparty governments.

Presidents are guided by more than the need to build support for their agenda in congress - they must also delegate significant authority over policy formulation, enactment, and implementation to ministers. Agency loss arises when ministers have political incentives to diverge from the president's [preferences] and employ this authority to pursue goals that conflict with the president's aims. (Martínez-Gallardo and Schleiter 2015, 2) 
Another strategy available to the president is the appointment of nonpartisan ministers. This is a viable strategy because the president has the prerogative to appoint ministers, and these can be either partisan representatives or some expert or bureaucrat who is expected to be loyal to the president (Martínez-Gallardo and Schleiter 2015).

Other possible strategies for controlling policy drift involve mechanisms of intracoalition monitoring, even after portfolio allocation. One possibility is the institutional development of the presidency that directly relates to the governing costs of multiparty coalitions. Inácio and Llanos (2016) show that multiparty governments are an incentive to the increase in this direct assistance to the president as a way to overcome informational asymmetries and monitor cabinet ministers. Pereira et al. (2016) demonstrate that the cost of monitoring partners is directly associated with presidents' choice of how to manage their coalitions. They show that large and ideologically diverse coalitions and disproportionate cabinets tend to be more difficult to coordinate and monitor, and consequently more expensive over time.

In addition to portfolio allocation, presidents may rely on multiple tools to build and manage coalitions. Raile et al. (2011) actually claim that portfolio and "pork" function as imperfect substitutes. Whereas the former establishes an exchange baseline, the latter covers the ongoing costs of coalition operation.

Another way the presidency can monitor coalition partners is through centralized screening of policy decisions. The president may use the direct support of the presidency to control cabinet ministers, allowing direct interference in the policymaking process when the minister is not aligned with the president (Batista 2013). Going beyond formal institutions, the president may use an informal advisory network to manage multiparty coalitions (Siavelis 2016). Outside the executive branch, coalition monitoring may occur as a mutual control strategy by coalition partners through the legislative committee system (Inácio and Rezende 2015).

We believe that because the existence and termination of a government are exogenously defined, it is even more important to understand coalition governance and how coalitions actually work. We follow the approach presented by MartínezGallardo and Schleiter (2015) that the president has to choose "whom to trust" so agency loss can be minimized. However, we argue that delegation problems cannot be anticipated and resolved completely in the portfolio allocation stage. Once ministers are appointed, there is always the possibility of moral hazard. Given this risk, the president may use a monitoring mechanism to minimize policy drift and keep delegation from degenerating into abdication.

We focus on the use of watchdog junior ministers as the main coalition-monitoring mechanism available to presidents in multiparty systems. The "junior minister" literature so far has been biased toward parliamentary democracies. However, coalition governments occur in 53.6 percent of the situations in which the president's party does not obtain a sufficient number of seats to govern alone (Cheibub et al. 2004, 574). This suggests that there is an important gap to be filled in the coalition management literature on multiparty presidential regimes, both theoretically and empirically. 
We argue that in presidential systems, the president may use appointments to cabinet positions, including junior ministers, as a strategy to minimize agency losses and the risk of policy drift. The president decides the portfolio allocation strategy, appointing loyal ministers to a specific share of portfolios. Partisan ministers, including those of the president's party, may face different electoral incentives, and for this reason may not be trusted in the decisionmaking process. Therefore, after portfolio allocation the president still faces agency risks, and removing cabinet ministers is costly, albeit not the only option. The president may monitor coalition partners by appointing loyal junior ministers to oversee partisan ministers.

Our focus is this second stage: after portfolio allocation, how presidents decide whom to monitor in coalition government decisionmaking. On the basis of the literature about coalition monitoring in parliamentary systems and the specialized literature on presidential systems, we expect the president to consider three different factors when deciding which ministers to monitor: ideological preference distance, portfolio salience, and coalition agreement.

Preference distance is the most-emphasized determinant of coalition partner monitoring. The greater the preference distance, the higher the risk of policy drift and thus the incentives for monitoring. We hypothesize that the greater the preference distance, identified as the ideological distance between the president and the minister, the more inclined the president will be to interfere directly in the particular portfolio delegated to that distant partner. It is reasonable to infer that policy preferences between them will not be perfectly aligned, so that policy decisions made by the minister can jeopardize the president's mandate. If that is the case, we should expect greater control from the president by, for instance, directly appointing a trusted junior minister to the specific ministry, delegated to watch an ideologically distant ally. On the other hand, the higher the degree of trust measured by the similarity of policy preference between the president and the minister, the less inclined the president will be to control that portfolio, and therefore the minister will have greater leverage to structure the ministry as desired.

We also analyze the effect of portfolio salience on the president's choice of how to monitor coalition allies, which is another important aspect tested in the pertinent literature. The greater the salience of the portfolio, the higher the cost the president would face in case of policy drift. According to Thies $(2001,586)$, "abdication is costless and monitoring pointless in areas of zero salience." Therefore we expect high incentives for the president to monitor coalition partners when the portfolio is of high salience. We also test the interaction between preference distance and portfolio salience. We expect that preference distance will be even more harmful to the president when such a partner controls a salient portfolio. Hence, we expect that the effect of preference distance will be greater in high-salience portfolios.

Last, we analyze the effect of the degree of "coalition agreement," or proportionality in portfolio allocation, on the monitoring of coalition partners. This factor is relevant only in presidential systems, since in parliamentary systems proportionality is the rule. There is evidence that coalitions reach some very different arrangements regarding distribution of portfolios and the amount of power coalition part- 
ners will have in government (Amorim Neto 2006). We argue that the coalescence rate is an indicator of the "quality of the agreement" among coalition partners. It is expected that the greater this agreement, the smaller the incentives for coalition monitoring.

In order to test these hypotheses, we explore the institutional design of coalition governments in Brazil, with emphasis on the powers of the president, minsters, and junior ministers in the decisionmaking process.

\section{Procedures and EMpirical Evidence: Brazil as a CASE STUdy}

To test the hypotheses presented above, we analyze Brazil from 1995 to 2010 . We argue that on this specific topic, a case study is the most viable approach because it offers the detailed knowledge necessary to understand the particular relationship between the actors in a decisionmaking process that often occurs behind closed doors. With a case study, it is possible to keep the institutional design constant and to identify what factors explain the relevant outcomes.

Our hypotheses address coalition governments in presidential systems, so we should choose a case study among the countries with this particular political system. Martínez-Gallardo and Schleiter (2015) show that Latin American countries vary greatly in the nature of coalition governments. Argentina experienced multiparty governments in 96 percent of the cases (1983-2011), Peru 80 percent (1985-1992, 2001-2011), Bolivia 38 percent (1983-2009), and Ecuador 20 percent (19842009). Chile (1990-2010), Brazil (1990-2010), and Uruguay (1985-2010) experienced multiparty governments throughout the period since redemocratization. Considering that we are testing hypotheses about coalition governance, those countries that systematically form coalition governments would be the natural candidates, due to variability in coalition composition. However, considering variation as an important precondition, an average coalition in Brazil includes 5.27 parties, while in Chile it includes an average of 3.85 and in Uruguay an average of 1.75 (Freudenreich 2016). For this reason we chose Brazil as case study because it can be considered an extreme case. According to Seawright and Gerring (2008), the choice of extreme cases to conduct case studies is one technique available to select cases based on empirical factors and not practical ones.

The Brazilian president has the constitutional prerogative to appoint both ministers and junior ministers. Formally, cabinet ministers are responsible for advising the president in matters of policymaking and policy implementation. This interpretation comes from the Brazilian Constitution and resembles the idea of an advisory body inspired by the U.S. cabinet (Fenno 1959). However, in practice, ministers represent the division of labor within the executive branch. Each minister develops expertise in the specific area, directly controlling policy implementation and budget allocation.

Specifically, ministers legally have technical, financial, and administrative autonomy. They are also responsible for formulating strategies and priorities in the 
implementation of the federal budget and for supervising federal agencies and stateowned companies. Policy formulation may come from the bottom, with ministers proposing changes, or from the top, with the president requesting decrees or bill drafts. This means that the ministers have an important role in the executive's decisionmaking, whether through direct action or through the use of their agenda-setting powers. For this reason, the president must monitor them to keep governmental decisions under control.

Junior ministers, or secretários executivos, as they are called in Brazil, are the second-in-command in the hierarchy of a ministry, and their appointment is legally defined. Every ministry has one junior minister, and their prerogatives include the supervision of federal bodies not directly subordinated to the minister and sometimes the supervision of the performance and goal achievement of every program coordinator in the ministry. In practice, this means that the junior minister is responsible for the technical aspects of policy implementation and budget allocation. More important, the junior minister has the responsibility of assisting the minister in the decisionmaking process; but in decisions on some issues they respond directly to the president. For this reason, the appointment of the junior minister can be an important strategy to monitor coalition partners.

There is plenty of anecdotal evidence suggesting that the strategy of appointing junior ministers has been prevalent in Brazil. For instance, the head of the Casa Civil disclosed in an interview,

[Fernando Henrique] Cardoso's administration was prodigal in using junior ministers to monitor coalition partners holding portfolios, especially from 1995 to 1998 . All public policies deemed as relevant and crucial to various policy areas were determined by three ministers with very close access to the president: Casa Civil, Fazenda, and Planejamento [President's chief of staff, Finance, Planning and Budget]. Junior ministers would then be appointed to keep the ministers in line with presidential directives. (Former Head of Casa Civil 2012)

Other examples are the presidential policy priorities, which were formalized in a document for all junior ministers, who kept a close eye on what the ministers were doing, even if it meant the disapproval of party leaders. A former junior minister of education mentioned a minister of previdência social (welfare), affiliated to the Partido da Frente Liberal (PFL), who was firmly held accountable by his party leaders for following the president and the head of Casa Civil instead of "implementing his own policies" (Former Junior Minister of Education 2013).

In her first term, President Dilma Rousseff of the Workers' Party was also pushed by the Partido da República (PR) to appoint a "professional politician" to head the Ministry of Transportation. She considered the possibility of appointing a watchdog "technocratic" junior minister to keep him in line (Lima et al. 2013). 


\section{Data and Methods}

To pursue our hypotheses empirically, we built an original dataset of 178 pairings of ministers and their respective junior ministers in Brazil from 1995 to 2010. We gathered data from different sources: the federal government's transparency website (www.transparencia.gov.br); the Ministry of Planning, via formal request using the recently enacted Freedom of Information Law; the Official Federal Gazette (Diário Oficial da Uniäo) for information regarding dates of appointments and resignations of junior ministers; and the Federal Electoral Court's list of the partisan affiliations of ministers and junior ministers. This novel dataset allows us to study, in a systematic manner, all the possible executive strategies in appointing junior ministers by two Brazilian presidents: Fernando Henrique Cardoso (PSDB) and Luiz Inácio Lula da Silva (PT), each of whom occupied the presidency for eight years (two terms).

As noted, a trusted junior minister may work as a sort of agent of the president within a ministry, watching the behavior and potential risk of policy drift of a partisan minister. We therefore are not interested in addressing the determinants of all presidential appointees, but instead focus our analytical assessment on the presidential choice of appointing watchdogs as a strategy of monitoring coalition partners. Our definition of watchdog is a junior minister appointed by the president and not aligned with the minister. Therefore we observe a watchdog junior minister when this appointee is a bureaucrat (nonpartisan) or member of a political party different from that of the minister.

This is precisely how we operationalized our dependent variable in all the econometric exercises: as a dummy to which we attribute the value of 1 if the junior minister, appointed by the president and in charge of overseeing a coalition partner, is from a different party or a career bureaucrat without partisan affiliation, and 0 otherwise. We are interested only in how the president monitors partisan ministers as a strategy to reduce the risk of policy drift. Since appointing a nonpartisan minister is already a maximum control strategy, we do not include these ministers in the analysis of coalition monitoring.

The most appropriate empirical strategy to test the main hypotheses is to use a logistic regression model. The unit of analysis of our dataset is the pairwise period in which a particular minister held a ministerial office at the time a junior minister also occupied that position in a particular ministry. Therefore, all variables in our analysis follow the organizational structure of this pairwise timeframe. We included only partisan ministers in our econometric analysis, since there is no logical expectation concerning the monitoring of nonpartisan ministers already appointed to maximize control.

When deciding on the monitoring options, the president will consider the following key aspects: the preference distance between the president's political party and the party of the coalition ally, the portfolio salience, the interaction between these two factors, and the degree of coalition agreement. We operationalize these variables as follows. 
Preferencelideological distance. The ideological distance between the president's political party and the minister's political party according to Power and Zucco's index (2009). We hypothesize that the greater the ideological distance between the president's party and the political party of the coalition partner, the greater the likelihood the president will appoint a watchdog junior minister in order to oversee the behavior and policy decisions of a coalition partner minister.

Portfolio salience. Portfolio salience is a measure of policy relevance based on the number of legislative initiatives by the ministry, as proposed by Batista (2017). We include only the policy dimension of the importance measure because we consider this to be the most important in terms of the president's strategy to minimize policy drift. We expect that the greater the portfolio salience, the greater the likelihood that the president will appoint a watchdog junior minister.

Coalition agreement/coalescence rate. The coalescence rate is the degree of proportionality between the number of cabinet positions and the number of seats that the coalition party contributes to the coalition in the lower chamber. The calculus is presented by Amorim Neto (2006), and we updated the data with information from the Câmara dos Deputados website. We expect that the greater the coalescence, the smaller the probability of monitoring.

As for controls, we have included the following variables:

President's popularity. The average of presidential popularity during the pairwise period of a particular minister and junior minister combination. The data are drawn from the Datafolha polling institute. Since Datafolha measures popularity intermittently, generally six to eight times per year, first we interpolated missing values to create a full coverage period. We then averaged the full series to create a single popularity value for each minister and junior minister combination during Cardoso's and Lula's administrations. Given that an admired president enjoys greater popular support, we expect that such a president would face fewer concerns about appointing watchdog junior ministers.

A dummy variable indicating whether the president is in the first term, facing re-election, or in the second term and therefore unable to be re-elected. We expect presidents in the second mandate to monitor their ministers more, since they face no electoral constraint in the near future.

A dummy variable for the administrations of President Lula capturing any "leadership style" differences compared to FHC.

\section{Descriptive Assessment}

In the 1995-2010 period we observe 178 minister and junior minister pairings. These pairings involve all portfolio allocation strategies implemented by the president: nonpartisan ministers (NP) and partisan ministers, both from the president's party (PP) and from other coalition parties (CP). Figure 1 shows the distribution of ministers by type.

The number of nonpartisan ministers corresponds to a proportion of 0.24 of the observations, showing that Brazilian presidents do implement the strategy of $a$ 
Figure 1. Portfolio Allocation and Monitoring Through Junior Ministers, $1995-2010$

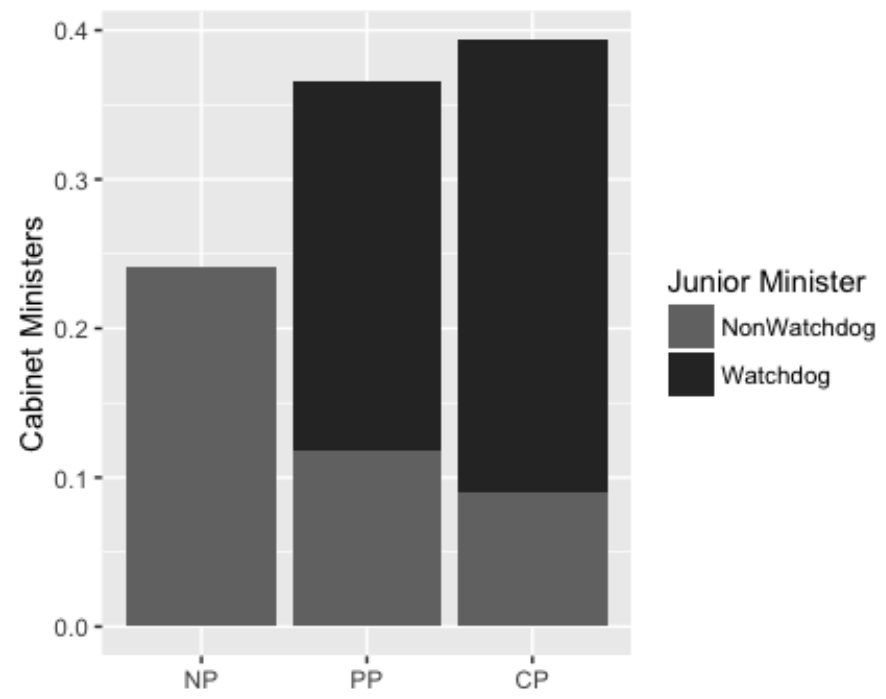

priori control, meaning that portfolios are allocated to ministers with no partisan affiliation and, by definition, more loyal to the president's preferences than partisan ministers (Martínez-Gallardo and Schleiter 2015). When the president appoints a nonpartisan minister, the appointment implements the maximum control strategy. Nonpartisan ministers are loyal only to the president and are usually considered part of the president's "personal quota." Because the president already has a fully trusted ally as the head of the ministry, there is no need for ex-post monitoring via watchdog. For this reason, in our theoretical framework, there is no logical need to appoint a junior minister to watch a nonpartisan minister, and therefore our empirical analysis focuses on monitoring partisan ministers.

Because the president still faces legislative incentives to form coalitions and therefore to allocate portfolios to partisan representatives, including from the president's own party, a proportion of 0.76 of the observations refers to partisan ministers ( 135 out of 178 in our sample), with 0.37 from the president's party and 0.39 from the other coalition parties. This means that in most cases the president deals with partisan ministers in the executive decisionmaking process. We argue that what happens after portfolio allocation also matters, and that the president may use the monitoring strategies when dealing with partisan ministers. In our sample, the president has to choose whom to trust among the partisan ministers, with a monitoring rate of 0.73 , indicating that of the 135 partisan ministers, junior ministers appointed by the president monitor 99 . The monitoring rate for the ministers from the president's party is 0.33 and for the ministers from the other coalition parties, 0.40. Even though other coalition parties face greater control than ministers from 
Table 1. Descriptive Statistics

\begin{tabular}{lcccccc}
\hline \hline Variable & & & & & Standard & \\
Deviation & $\%$ \\
\hline Watchdog & 135 & 0 & 1.0 & - & - & 72.6 \\
Ideological distance & 134 & 0 & 4.50 & 0.903 & 1.213 & - \\
Portfolio salience & 135 & -0.713 & 3.031 & -0.032 & 0.795 & - \\
Coalescence & 135 & 0.46 & 0.54 & 0.582 & 0.049 & - \\
Presidential popularity & 135 & -35.40 & 73.00 & 17.128 & 24.807 & - \\
Mandate & 135 & 0 & 1.0 & - & - & 48.8 \\
Lula & 135 & 0 & 1.0 & - & - & 53.0 \\
\hline \hline
\end{tabular}

the president's party, partisan loyalists are also subject to electoral incentives and are monitored to keep governmental decisions aligned with the president's preferences.

This evidence shows that the president uses watchdogs to monitor coalition partners and coordinate government decisionmaking in the executive branch. In our definition, a watchdog can be a partisan or a career bureaucrat. Despite the different backgrounds, both act as the president's agent. However, some clarifications are in order. The appointment of a partisan as junior minister is straightforward in the literature, but the concept of a bureaucrat working as a president's watchdog is a peculiar organizational feature of the Brazilian public service. A nonpartisan junior minister usually comes from the public sector and also enjoys a tenured career. It is common knowledge, however, that once appointed by the president to work as a junior minister, this career bureaucrat, in addition to sharing policy preferences, renders gratitude and loyalty to the president for occupying a top bureaucratic position in the public service, which provides access to a higher salary, a greater reputation, and powerful influence. Bureaucratic watchdogs appear in 69.4 percent of our observations and political watchdogs in 20.6 percent.

Given that the president does indeed use watchdogs to monitor coalition partners but that this strategy is not universally implemented, which ministers will be monitored and which will not? Table 1 shows descriptive statistics of our variables.

Another important descriptive aspect to observe is the frequency distribution of watchdogs by policy areas. To what extent does the executive prioritize specific portfolios to monitor coalition partners with watchdogs? Table 2 shows that the policy areas with the highest frequency of watchdogs are legal policy and government management ( 88 percent), other ministries ( 83 percent), social policy (63 percent), and infrastructure (61 percent), respectively. The only policy area in which presidents have mostly preferred not to appoint watchdogs is economic policy (33 percent). Because this policy area has been the most highly valued branch of the government, given that presidents cannot credibly transfer the blame if something goes wrong with the economy, ministries of this particular portfolio are usually very close to presidents' preferences. Thus, presidents do not need to establish ostensive monitoring mechanisms. In other policy areas that are more susceptible to being delegated 
Table 2. Frequency Distribution of Watchdog by Policy Areas, 1995-2010

\begin{tabular}{lll}
\hline \hline & Watchdog & Nonwatchdog \\
\hline Development, science, and technology & $57 \%(4 / 7)$ & $43 \%(3 / 7)$ \\
Economic policy & $33 \%(1 / 3)$ & $66 \%(2 / 3)$ \\
Infrastructure & $61 \%(17 / 28)$ & $39 \%(11 / 28)$ \\
Legal policy and government management & $88 \%(15 / 17)$ & $12 \%(2 / 17)$ \\
Social policy & $63 \%(32 / 51)$ & $37 \%(19 / 51)$ \\
Other & $83 \%(24 / 29)$ & $17 \%(5 / 29)$ \\
\hline \hline
\end{tabular}

to coalition allies, it makes more sense for presidents to keep a close eye on the performance of partners via watchdogs.

Out of the 178 pairings, we analyze all 135 (72.6 percent) that include a partisan minister and the logical possibility of monitoring, according to our argument (the appointment of nonpartisan ministers as a strategy for controlling policies implemented in the portfolio allocation stage). This is our dependent variable. Our first independent variable is ideological distance. It ranges from 0 to 4.50 with a mean of 0.79 . Portfolio salience is standardized and varies from a minimum of -0.73 to a maximum of 3.03. Coalescence is an index that varies from 0 to 1 . The mean coalescence rate in our observations is 0.582 , very different from the 0.9 observed in parliamentary systems. Presidential popularity has a mean of 17.2 percent. Our observations take place 48.8 percent in the president's second term and 53 percent during President Lula's administrations.

\section{Multivariate Analysis}

The analyses shown in table 3 include four distinct administrations of two presidents of different ideological positions and orientations. Table 3 shows different model specifications estimating the impact of our core independent variables on the probability that the president will appoint a junior minister to monitor a coalition partner. Model 1 presents the results for ideological distance, portfolio salience, and coalescence. Model 2 includes control variables. Model 3 includes the interaction term between ideological distance and portfolio salience. These different specifications serve the purpose of testing the robustness of the results.

In all model specifications the ideological distance presents the expected sign and statistical significance, indicating that when policy preferences between the president and the coalition partner are not aligned, the president will try to minimize agency losses and risks of policy drift by appointing a trusted junior minister.

Portfolio salience appears with the predicted sign in all models, indicating that the greater the salience of the portfolio the greater the probability of monitoring. However, this variable does not show statistical significance in any of the models, suggesting that the president's concern with key policy issue areas was not strong enough to lead the executive to extensively monitor those cabinet positions with a 
Table 3. Political Determinants of Appointing Coalition Watchdogs in Multiparty Presidential Systems

\begin{tabular}{|c|c|c|c|c|c|c|}
\hline & Model 1 & $\begin{array}{l}\text { Odds } \\
\text { Ratio }\end{array}$ & Model 2 & $\begin{array}{l}\text { Odds } \\
\text { Ratio }\end{array}$ & Model 3 & $\begin{array}{l}\text { Odds } \\
\text { Ratio }\end{array}$ \\
\hline Ideological distance & $\begin{array}{l}0.553^{* * *} \\
(0.207)\end{array}$ & $1.738^{* * *}$ & $\begin{array}{l}0.590^{* * *} \\
(0.215)\end{array}$ & $1.804^{* * *}$ & $\begin{array}{l}1.032^{* *} \\
(0.524)\end{array}$ & $2.807^{* *}$ \\
\hline Portfolio salience & $\begin{array}{c}0.374 \\
(0.273)\end{array}$ & 1.453 & $\begin{array}{c}0.231 \\
(0.288)\end{array}$ & 1.261 & $\begin{array}{c}0.129 \\
(0.291)\end{array}$ & 1.138 \\
\hline Ideology*Salience & - & - & - & - & $\begin{array}{c}0.982 \\
(0.920)\end{array}$ & 2.671 \\
\hline Coalescence & $\begin{array}{c}-2.751 \\
(4.156)\end{array}$ & .063 & $\begin{array}{c}-1.794 \\
(5.140)\end{array}$ & .166 & $\begin{array}{c}-1.817 \\
(5.108)\end{array}$ & .162 \\
\hline $\begin{array}{l}\text { Presidential } \\
\text { popularity }\end{array}$ & - & - & $\begin{array}{c}0.025^{*} \\
(0.014)\end{array}$ & $1.026^{*}$ & $\begin{array}{c}0.024^{*} \\
(0.014)\end{array}$ & $1.025^{*}$ \\
\hline Mandate & - & - & $\begin{array}{c}-0.706 \\
(0.611)\end{array}$ & .493 & $\begin{array}{c}-0.665 \\
(0.615)\end{array}$ & .513 \\
\hline Lula & - & - & $\begin{array}{c}-2.355^{* * *} \\
(0.862)\end{array}$ & $.094^{* * *}$ & $\begin{array}{c}-2.278^{* * *} \\
(0.877)\end{array}$ & $.102^{* * *}$ \\
\hline Constant & $\begin{array}{c}2.158 \\
(2.425)\end{array}$ & 8.659 & $\begin{array}{c}2.810 \\
(2.910)\end{array}$ & 16.623 & $\begin{array}{c}2.765 \\
(2.885)\end{array}$ & 15.883 \\
\hline $\mathrm{N}$ & \multicolumn{2}{|c|}{131} & \multicolumn{2}{|c|}{131} & \multicolumn{2}{|c|}{131} \\
\hline $\mathrm{R}^{2}$ & \multicolumn{2}{|c|}{0.061} & \multicolumn{2}{|c|}{0.127} & \multicolumn{2}{|c|}{0.138} \\
\hline Log likelihood & \multicolumn{2}{|c|}{-73.192} & \multicolumn{2}{|c|}{-68.048} & \multicolumn{2}{|c|}{-67.150} \\
\hline $\mathrm{LrChi}^{2}$ & \multicolumn{2}{|c|}{$9.57^{* *}$} & \multicolumn{2}{|c|}{$19.86^{* * *}$} & \multicolumn{2}{|c|}{$21.65^{* * *}$} \\
\hline
\end{tabular}

${ }^{*} \mathrm{p}<.10,{ }^{* *} \mathrm{p}<.05,{ }^{* * *} \mathrm{p}<.01$

Notes: Logistic regression with appointment of watchdog as dependent variable (value of 1 if the appointee is a watchdog and 0 otherwise). Coefficients reported, standard errors in parentheses.

trustable watchdog. This result is similar to what Carroll and Cox (2012) obtained with regard to the role of legislative committees monitoring coalition partners in parliamentary regimes. In model 3, the interaction between salience and ideological distance, even though the sign is what we expected, this interaction, too, is not statistically significant.

Concerning the specifications with control variables (models 2 and 3), their inclusion does not change the sign of our key independent variables. All three controls appear with the expected sign, and presidential popularity, as well as the dummy for Lula's administrations, is statistically significant. This means that the greater the president's popularity, the greater the probability of monitoring. Also, Lula's administrations were marked by less monitoring of coalition partners than FHC's administrations. 
Figure 2. Predicted Probability Logistic Regression (with Controls): Ideological Distance (95 percent CIs)

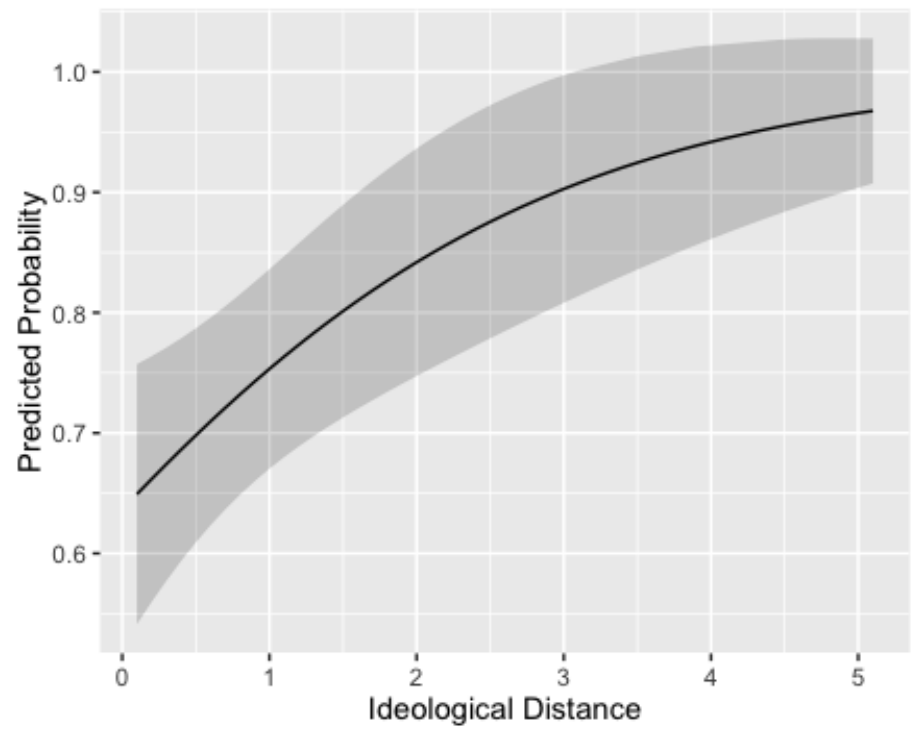

Of our main three variables, only ideological distance shows statistical significance in all three models. Another way of observing the substantive impact of this variable on the president's decision to assign a watchdog to a specific portfolio is to estimate the predicted probability of appointing a watchdog holding all other variables in the model at their means. For instance, figure 2 shows the predicted probability of appointing a watchdog junior minister for the different levels of ideological distance.

For a minister with ideological distance of 0 , the predicted probability of a watchdog minister to be appointed is 0.64 . The predicted probability increases to 0.81 when the ideological distance between the minister and the president is 2 , and to 0.95 when the ideological distance reaches 4.5 , the maximum value in our distribution. Therefore, analyzing the president's monitoring strategies concerning coalition partners in Brazil, our main result is that the greater the ideological distance, the greater the probability of monitoring. Surely there are unobserved factors that must be taken into account; for example, the existence of internal factions in the president's party. Surely this result might seem simple. However, there is strong evidence that coalition partners use junior ministers to keep each other under control in parliamentary systems and that ideological distance is the main predictor in the monitoring decision. Here we show the first evidence that this is also a viable strategy in Latin American presidential systems, particularly in the coalitional presidentialism of Brazil. 


\section{Conclusions}

This article addressed delegation dilemmas presidents face when they have to manage multiparty coalitions. Managing multiparty coalitions in presidential regimes does not seem to be a trivial task. On many occasions, chief executives have to deal with too many and too ideologically diverse coalition partners, as well as having to decide the amount of power to share with them. On the one hand, presidents should benefit from delegating sufficient authority and flexibility to coalition allies occupying ministerial positions, allowing them to accomplish their job well in their specific policy area. By doing so, however, presidents run the risk of being expropriated by subordinate ministers if the latter decide to implement policies counter to presidential preferences.

In order to deal with these difficult choices and avoid being expropriated by policy drift, presidents may decide, for instance, to exercise control over the behavior and policy decisions of subordinated partners in their cabinets by appointing someone trusted who could exercise the role of a presidential watchdog. This kind of ostensive police patrol mechanism (McCubbins and Schwartz 1984), in addition to having the potential to harm the relationship with coalition partners, can introduce numerous procedural rigidities that ultimately can lead to inefficient policy implementation (Huber and Shipan 2002). On the other hand, presidents may prefer to implement a much looser control of subordinates, allowing greater discretion to ministers to appoint bureaucrats and make policy decisions without the ostensive presence of someone directly watching the portfolio.

This study particularly investigated the extent to which junior ministers, the second rank in the policymaking ministerial hierarchy, play the role of presidential watchdogs in multiparty coalitional settings, taking Brazil as a case study. We claim that the president balances political support and policy control when deciding how to monitor coalition partners. Specifically, we claim that the president's managerial choice of monitoring coalition partners is constrained by three interconnected political features: the ideological distance between political parties in the governing coalition, the salience of the particular portfolio, and the concentration of cabinet posts in the president's political party.

This study finds that presidents make use of junior ministers as watchdogs when ideological differences between coalition parties and the president's party are substantial. This indicates that ideology matters beyond the floor of the legislature and is indeed pervasive in the executive branch among coalition allies. Portfolio salience presents the expected positive sign, indicating that the greater the salience, the greater the probability of a watchdog junior minister. However, this result does not achieve statistical significance. Similar results were also obtained with regard to sharing policy preferences with coalition partners. As we expected, the president will be more inclined to monitor coalition partners with watchdogs when powers are not shared with political allies. But the confidence level of this variable, too, was not statistically significant.

These results suggest interesting theoretical and empirical implications for the comparative study of coalition monitoring in multiparty presidential regimes. The- 
oretically, the literature on coalition monitoring and management has focused on parliamentary systems, even though coalitional presidentialism has become increasingly common (Chaisty et al. 2012). Our argument that the president balances political support and policy control when choosing to monitor coalition partners through watchdog junior ministers dialogues directly with the parliamentary literature, but refers to the specifics of the presidential system and offers institutional variation to a literature that until now was restricted to parliamentary cases. Empirically, we offer an original assessment of the use of watchdog junior ministers to monitor coalition partners in Brazil, systematically testing the effect of four important aspects of coalition management in presidential systems.

Although we specifically investigate the political dilemma that Brazilian presidents have faced deciding how to manage and monitor coalition partners, we hope that the particular theoretical and empirical exercises we propose here could travel well and extend to other multiparty presidential regimes elsewhere.

\section{NoTE}

Previous versions of this article were presented at the International Workshop on Coalition Management in Multiparty Presidentialism in Comparative Perspective, EBAPE/FGV, September 13, 2013; at the 7th Congress of the Latin American Political Science Association (ALACIP), Bogotá, September 25-27, 2013; and in the IPEA Seminar, Brasília, December 12, 2013. The Institute of Applied Economic Research (IPEA) funded this project. We are very grateful to Cecilia Martínez-Gallardo, Timothy Power, Marcus André Melo, Octavio Amorim Neto, and Acir Almeida for their comments and suggestions. We also thank Frederico Bertholini for his research assistance.

\section{REFERENCES}

Alemán, Eduardo, and George Tsebelis. 2011. Political Parties and Government Coalitions in the Americas. Journal of Politics in Latin America 3, 1: 3-28.

Amorim Neto, Octavio. 2006. The Presidential Calculus: Executive Policymaking and Cabinet Formation in Latin America. Comparative Political Studies 39, 4: 415-40.

Araya, Ignacio A. 2012. ¿Quién le susurra al presidente? Asesores vs. ministros en América Latina. Revista de Ciencia Política 50, 2: 33-61.

Batista, Mariana. 2013. O poder no executivo: uma análise do papel da presidência e dos ministérios no presidencialismo de coalizão brasileiro (1995-2010). Opiniáo Pública 19, 2: 449-73.

- 2017. Taking Portfolios Difference Seriously: A Composite Measure Based on Policy, Office, and Budget in Brazil. Brazilian Political Science Review 11, 1: 1-28.

Carroll, Royce, and Gary Cox. 2012. Shadowing Ministers: Monitoring Partners in Coalition Governments. Comparative Political Studies 45, 2: 220-36.

Chaisty, Paul, Nic Cheeseman, and Timothy Power. 2012. Rethinking the Presidentialism Debate: Coalitional Politics in Cross-Regional Perspective. Democratization 21, 1:7194.

Cheibub, José Antônio, Adam Prezeworski, and Sebastian Saiegh. 2004. Government Coalition and Legislative Success Under Presidentialism and Parliamentarism. British Journal of Political Science 34: 565-87. 
Fenno, Richard F. 1959. The President's Cabinet: An Analysis in the Period from Wilson to Eisenhower. Cambridge: Harvard University Press.

Ferraro, Agustín. 2008. Friends in High Places: Congressional Influence on the Bureaucracy in Chile. Latin American Politics and Society 50, 2 (Summer): 101-29.

Former Head of Casa Civil. 2012. Author interview. São Paulo, November 26.

Former Junior Minister of Education. 2013. Author interview. São Paulo, March 6.

Freudenreich, Johannes. 2016. The Formation of Cabinet Coalitions in Presidential Systems. Latin American Politics and Society 58, 4 (Winter): 80-102. Harvard Dataverse V1.

Gamson, William A. 1961. A Theory of Coalition Formation. American Sociological Review 26, 3: 373-82.

Giannetti, Daniela, and Michael Laver. 2005. Policy Positions and Jobs in the Government. European Journal of Political Research 44, 1: 91-120.

Huber, John D., and Charles R. Shipan. 2002. Deliberate Discretion? The Institutional Foundation of Bureaucratic Autonomy. Cambridge: Cambridge University Press.

Inácio, Magna, and Daniela Rezende. 2015. Partidos legislativos e governo de coalizão: controle horizontal das políticas públicas. Opinião Pública 21, 2: 296-335.

Inácio, Magna, and Mariana Llanos. 2016. The Institutional Presidency in Latin America: A Comparative Analysis. Presidential Studies Quarterly 46, 3: 531-49.

Indridason, Indridi H., and Gunnar Helgi Kristinsson. 2013. Making Words Count: Coalition Agreements and Cabinet Management. European Journal of Political Research 52: $822-46$.

Kim, Dong-Hum, and Gerard Loewemberg. 2005. The Role of Parliamentary Committees in Coalition Government: Keeping Tabs on Coalition Partners in the German Bundestag. Comparative Political Studies 38, 9: 1104-29.

Laver, Michael. 1998. Models of Government Formation. Annual Review of Political Science $1,1: 1-25$.

Laver, Michael, and Kenneth A. Shepsle. 1990. Coalitions and Cabinet Government. American Political Science Review 84, 3: 873-90.

. 1996. Making and Breaking Governments: Cabinets and Legislatures in Parliamentary Democracies. Cambridge: Cambridge University Press.

Laver, Michael, and Kenneth A. Shepsle, eds. 1994. Cabinet Ministers and Parliamentary Government. Cambridge: Cambridge University Press.

Lima, Maria, Luiza Damé, and Catarina Alencastro. 2013. Dilma define reforma ministerial em reunião com Temer. Anúncio oficial deverá ser feito ainda nesta semana. O Globo, March 13. http://oglobo.globo.com/pais/dilma-define-reforma-ministerial-em-reuniaocom-temer-7824598. Accessed March 13, 2013.

Lipsmeyer, Christine S., and Heather Nicole Pierce. 2011. The Eyes that Bind: Junior Ministers as Oversight Mechanisms in Coalition Governments. Journal of Politics 73, 4: 1152-64.

Loureiro, Maria Rita, Cecília Olivieri, and Ana Cristina Braga Martes. 2010. Burocratas, partidos e grupos de interesse: o debate sobre política e burocracia no Brasil. In Burocracia e politica no Brasil: desafios para o estado democrático no século XXI, ed. Loureiro, Fernando Abrucio, and Regina Pacheco. Rio de Janeiro: Fundação Getúlio Vargas. 73-108.

Martin, Lanny W., and Georg Vanberg. 2011. Parliaments and Coalitions: The Role of Legislative Institutions in Multiparty Governance. Oxford: Oxford University Press.

Martínez-Gallardo, Cecilia. 2010. Inside the Cabinet: The Influence of Ministers in the Policymaking Process. In How Democracy Works: Political Institutions, Actors, and Arenas in Latin American Policymaking, ed. Carlos Scartascini, Ernesto Stein, and Mariano Tommasi. Cambridge: Harvard University Press. 119-45. 
2012. Out of the Cabinet: What Drives Defections from the Government in Presidential Systems? Comparative Political Studies 45, 1: 62-90.

Martínez-Gallardo, Cecilia, and Petra Schleiter. 2015. Choosing Whom to Trust: Agency Risks and Cabinet Partisanship in Presidential Democracies. Comparative Political Studies 48, 2: 231-64.

McCubbins, Matthew, and Thomas Schwartz. 1984. Congressional Oversight Overlooked: Police Patrols versus Fire Alarms. American Journal of Political Science 28, 1: 16-79.

Müller, Wolfgang C., and Kaare Strøm. 2000. Coalition Governments in Western Europe. Oxford: Oxford University Press.

Müller, Wolfgang C., Torbjörn Bergman, and Kaare Strøm. 2010. Coalition Theory and Cabinet Governance: An Introduction. In Cabinets and Coalition Bargaining: The Democratic Life Cycle in Western Europe, ed. Strøm, Müller, and Bergman. Oxford: Oxford University Press. 1-50.

Pereira, Carlos, Frederico Bertholini, and Eric Raile. 2016. All the President's Men and Women: Coalition Management Strategies and Governing Costs in a Multiparty Presidency. Presidential Studies Quarterly 46, 3: 550-68.

Power, Timothy, and Cesar Zucco. 2009. Estimating Ideology of Brazilian Legislative Parties, 1990-2005. Latin American Research Review 44, 1: 218-46.

Raile, Eric, Carlos Pereira, and Timothy Power. 2011. The Executive Toolbox: Building Legislative Support in a Multiparty Presidential Regime. Political Research Quarterly 64, 2: 323-34.

Rehren, Alfredo. 1992. Liderazgo presidencial y democratización en el Cono Sur de América Latina. Revista de Ciencia Política 14, 1: 63-87.

Seawright, Jason, and John Gerring. 2008. Case Selection Techniques in Case Study Research: A Menu of Qualitative and Quantitative Options. Political Research Quarterly 61, 2: 294-308.

Siavelis, Peter M. 2016. Cabinets and Informal Advisory Networks in Multiparty Presidential Systems. Presidential Studies Quarterly 46, 3: 569-91.

Thies, Michael. 2001. Keeping Tabs on Partners: The Logic of Delegation in Coalition Governments. American Journal of Political Science 45, 3: 580-98.

Verzichelli, Luca. 2008. Portfolio Allocation. In Cabinets and Coalition Bargaining: The Democratic Life Cycle in Western Europe, ed. Kaare Strøm, Wolfgang C. Müller, and Torbjörn Bergman. Oxford: Oxford University Press. 237-68. 